\title{
Obituary Sir Rupert Cross
}

With the death of Rupert Cross on 12 September 1980, academic lawyers in the common law world have lost one of their most distinguished, most respected and best-loved colleagues.

Rupert's career as a law teacher began in 1944, at the Law Society's School of Law. Two years later, he came to Oxford as a parttime lecturer (and later as a Fellow) at Magdalen College; and he remained a member of the Oxford Law Faculty for the rest of his life. He was also well known as a special lecturer and visiting professor in many universities in the United Kingdom, the Commonwealth, Israel and the United States. From 1964 until his retirement in 1979 he was Vinerian Professor of English Law; and there can be no doubt that he was one of the truly great holders of that Chair. This claim rests principally on his published work, but also in part on his teaching, his service to law reform, and his personality.

The statistics relating to his publications are awesome. He was author or co-author of ten books, running between them into thirtynine editions, for all but a handful of which he was solely or mainly responsible. In addition, he published over fifty articles in learned Journals, not to mention notes and reviews. If from this formidable list one item stands out as pre-eminent, it is, of course, his great work on Evidence, which ranks as one of the outstanding legal textbooks produced in England in the present century. Before 1958, there was simply no comprehensive academic work on the English law of Evidence. Cross on Evidence filled the gap, and, in so doing, it immeasurably raised the standard of discussion of the subject in England and the Commonwealth. The book not only filled this gap, but also helped to bridge another - that between academics and practitioners. There are very few law books of which it can be said that they provide an equally rich source of material for a University seminar and for an argument before the House of Lords; and fewer still of which this is true from their very inception. Cross on Evidence served both purposes from the time of its first publication; and in this respect its importance transcends the law of Evidence.

As a teacher, Rupert was brilliant and exciting. In lectures, he had the gift of being able to instruct, stimulate and entertain, all at the same time. In seminars and tutorials, this gift was combined with a rare ability to make use of the student's own contribution (however misguided) as an essential part of the teaching process. The resulting sense of participation added to the excitement and enjoyment of being one of his pupils.

In this Journal, it seems right to concentrate attention on Rupert's work as a scholar and teacher, but something should also be said of his 
service to Law Reform. Much of this was rendered in his capacity as a member of the Criminal Law Revision Committee. The fate of that Committee's Eleventh Report must have been a disappointment to him; and it remains to be seen whether at least some of the controversial proposals made in that Report will not ultimately prevail. In other areas of law reform, reports for which he was partly responsible had more immediate success: for example, in the law relating to suicide, juries and theft.

His remarkable personality is impossible to capture in a few sentences, but a number of salient points stand out. There is, first, the fact that he totally overcame his blindness, being helped in this respect by a remarkable memory, and (as he often emphasized) by the indispensable and yet wholly self-effacing efforts of his wife, Heather. Then there was the delight of discussions with Rupert on innumerable topics. After talking to him about any legal question (even outside the areas in which he principally worked) one invariably felt that one had learned something new - or needed to make a fresh start. As a listener he was sympathetic; as a critic trenchant, but invariably constructive. For many of us, Rupert was a mentor, not merely in academic matters, but also in a much broader sense. 'Ask Rupert' had become a standard reaction, because so often he steered us in an obvious direction which had been previously overlooked.

He will be missed again and again by those many friends who enjoyed his company and benefited from his wisdom.

G. H. TREITEL 